\title{
THE EFFECT OF DIFFERENT LIGHT COLORS ON THE BIOMASS GROWTH OF Spirulina platensis
}

\author{
Putri Hanryani $^{1 *}$, Efriyeldi ${ }^{2}$, Irwan Effendi ${ }^{2}$ \\ ${ }^{1}$ Student of The Faculty of Fisheries And Marine Science University of Riau, Pekanbaru \\ ${ }^{2}$ Lecturer at the Faculty of Fisheries And Marine Science University Riau, Pekanbaru \\ *Putrihanryani@gmail.com
}

\begin{abstract}
Spirulina is microalgae that spreads widely in nature and can be found in various types of environments, both in brackish, sea and fresh water. Spirulina is photoautotrophic, so it requires light as an energy source for cell growth and synthesis of various important substances involved in it. Lack of light can cause photosynthesis to not take place normally so that it will affect the growth of $S$. platensis. This study aims to determine the effect of different light colors on the biomass growth of $S$. platensis. This research was conducted from March to April 2019 at the Marine Microbiology Laboratory and the Marine Chemistry Laboratory, Faculty of Fisheries and Marine, Universitas Riau. The method used in this research was the experimental method. The study design used was a completely randomized design (CRD) with four treatments (red, yellow, blue and control colors) and three replications. The results showed that the light colors had a significant effect on the biomass growth of S. platensis. Yellow light gave the best biomass growth, followed by red and blue light.
\end{abstract}

Keywords: Microalgae, Spirulina platensis, Light color

\section{PENDAHULUAN}

Mikroalga atau ganggang adalah organisme perairan yang dapat melakukan fotosintesis dan hidup dari nutrien anorgani $\mathrm{k}$ dan menghasilkan zat-zat organik melalui proses fotosintesis. Tumbuhan ini tampak warna-warni indah sesuai dengan zat warna atau pigmen yang dikandungnya.

Salah satu genus yang termasuk kedalam mikroalga di perairan yaitu Spirulina. Mikroalga

ini tergolong dalam divisi Cyanophyta yang memiliki warna biru kehijauan. Spirulina bersifat fotoautotrof sehingga membutuhkan cahaya sebagai sumber energi untuk pertumbuhan sel dan sintesis berbagai substansi penting yang terlibat di dalamnya. Kekurangan cahaya dapat mengakibatkan proses fotosintesis tidak berlangsung normal sehingga akan mempengaruhi pertumbuhan $S$. platensis (Ekawati, 2005).

Cahaya dapat dibedakan menjadi dua yaitu cahaya alami dan cahaya buatan. Adapun cahaya alami yang dimaksud adalah cahaya matahari dimana cahaya matahari adalah sumber energi utama bagi kehidupan seluruh makhluk hidup didunia. Lampu pijar (bohlam) adalah sumber cahaya buatan yang dihasilkan melalui penyaluran arus listrik melalui filament yang kemudian memanas dan menghasilkan cahaya. Kaca yang menyelubungi filament panas tersebut menghalangi udara untuk berhubungan dengannya sehingga filament tidak akan langsung rusak akibat teroksidasi.

Penggunaan Spirulina di berbagai industri mengakibatkan konsumsi Spirulina dari tahun ke tahun semakin meningkat. 
Mengingat bahwa Spirulina memiliki beragam jenis pemanfaatannya mulai dari obat-obatan, kosmetik sampai pangan manusia Berbagai penelitian dan pengembangan telah dilakukan untuk memproduksi biomassa $S$. platensis yang meliputi teknik kultur dalam berbagai skala produksi, optimasi kondisi lingkungan kultur, dan uji galur S. platensis (Reinehr dan Costa, 2006). Penelitian yang telah dilakukan terkait dengan cahaya sudah dilakukan terhadap klorofil, sementara untuk berat biomassa dengan warna cahaya merah, kuning dan biru belum ditemukan. Untuk itu penulis tertarik melakukan penelitian lebih lanjut tentang pertumbuhan biomassa $S$. platensis dengan pengaruh warna cahaya yang berbeda. Tujuan dari penelitian ini untuk mengetahui pengaruh warna cahaya berbeda terhadap pertumbuhan biomassa mikroalga $S$. platensis.

\section{METODE PENELITIAN}

Penelitian ini dilakukan dari bulan Maret - April 2019. Pemeliharaan dan perhitungan biomassa dilaksanakan di Laboratorium Mikrobiologi Laut dan Laboratorium Kimia Laut, Fakultas Perikanan dan Kelautan Universitas Riau.

Metode yang digunakan dalam penelitian ini adalah metode eksperimen. Rancangan penelitian yang digunakan adalah Rancangan Acak Lengkap (RAL) dengan empat perlakuan dan tiga ulangan, sebab pada penelitian ini semua dikondisikan sama kecuali warna cahaya yang diberikan, artinya tidak ada faktorfaktor lain yang dapat dianggap berpengaruh terhadap hasil pengamatan (Kusriningrum, 2008). Terdapat 4 perlakuan cahaya dari lampu pijar antara lain perlakuan (A) warna cahaya merah, perlakuan. (B) warna cahaya kuning dan perlakuan (C) warna cahaya biru. Untuk kontrol (K) menggunakan cahaya dari ruangan.
Pada penelitian ini, bibit yang diperoleh dari Jakarta sebanyak $600 \mathrm{ml}$ langsung dibuat stok kultur dengan cara menambahkan 3L air laut, lalu aduk rata dan dibiarkan selama 1 hari Air laut yang sudah disediakan diatur salinitasnya menggunakan handrefractometer menjadi $25 \%$, sesuai dengan hasil penelitian sebelumnya bahwa kadar salinitas biomassa S.platensis yang baik adalah 25\%o (Sintya,2018). Bibit $\quad S$. platensis dimasukkan sama banyak ke dalam 12 toples yang bervolume 1,5 L sebanyak 100 $\mathrm{ml}$, kemudian ditambahkan air laut sebanyak $1000 \mathrm{ml}$, serta dimasukkan pupuk awal sebanyak $10 \mathrm{ml}$ kedalam masingmasing wadah kultur. Setelah semua tercampur, toples diberi aerasi dan dipasangkan lampu 15 watt masing-masing bewarna kuning, merah dan biru untuk pencahayaan selama 24 jam setiap harinya. Pencahayaan diberi sekat agar tidak berpengaruh pada wadah kultur yang lainnya. Kultur dilaksanakan selama 15 hari, dan diamati setiap dua hari sekali untuk melihat laju perkembangan biomassanya serta diukur parameter kualitas air setiap harinya pada waktu yang sama agar selalu dalam keadaan terkontrol.

Teknik penyamplingan yang dilakukan yaitu kultur spirulina diambil 20 ml dan dituangkan ke dalam gelas ukur, lalu amati perubahan warna setiap proses penyamplingan, kemudian kultur disaring dengan menggunakan kertas saring yang berukuran 4-6 $\mu \mathrm{m}$ yang sudah dipersiapkan pada tahap preparasi dan sterilisasi, lalu kertas saring diletakkan pada vacum filter untuk menyaring kultur yang disampling tadi, setelah semua tersaring sempurna, kertas saring diangkat dari vacum filter menggunakan pinset dan diletakkan kembali ke alumunium foil. Selanjutnya kultur yang sudah disaring, dimasukkan ke dalam oven dengan suhu $105^{\circ} \mathrm{C}$ selama 2 jam. Setelah dioven selama 2 jam, lalu keluarkan dari oven. Kemudian ditimbang dengan menggunakan timbangan analitik, 
dan dicatat beratnya. Maka berat biomassa kultur spirulina yang didapat dikurangi berat kertas saring saja, yang mana pada tahap preparasi dan sterilisasi kertas saring sudah ditimbang sebelumnya atau dengan menggunakan rumus (BPPT, 2013):

$$
\mathrm{PB}=\frac{\Delta \mathrm{W}(\mathrm{W} 1-\mathrm{W} 0)}{\mathrm{V}}
$$

Keterangan:

$\mathrm{PB}=$ Pertumbuhan Biomassa $(\mathrm{g} / \mathrm{ml})$

$\mathrm{V}=$ Volume $(\mathrm{ml})$

$\mathrm{W}_{1}=$ Berat kertas saring + Berat kultur $(\mathrm{gr})$

$\mathrm{W}_{0}=$ Berat Kertas saring $(\mathrm{gr})$

\section{Analisis Data}

Data yang diperoleh disajikan dalam bentuk tabel dan grafik. Kemudian data kerapatan biomassa yang diperoleh diuji normalitas dan homogenitasnya. Selanjutnya untuk mengetahui pengaruh warna cahaya maka dilakukan uji Analysis of Variance (ANOVA). Apabila menunjukkan adanya pengaruh yang nyata dimana $\mathrm{F}_{\text {hit }}>\mathrm{F}_{\mathrm{tab}}$, selanjutnya dilakukan uji lanjut Least Significant Difference (LSD) untuk menentukan perlakuan yang mana yang memberikan hasil lebih baik (Sudjana, 1989). Hasil yang diperoleh dibahas secara deskriptive yang mengacu pada literatur.

\section{HASIL DAN PEMBAHASAN Parameter Kualitas Air}

Dari pengukuran kualitas perairan yang didapatkan selama penelitian ini berlangsung, dihasilkan bahwa kualitas air yang digunakan untuk melakukan kultur dalam kondisi terkontrol yaitu dengan ratarata suhu perairan berkisar $31-32^{\circ} \mathrm{C}, \mathrm{pH}$ berkisar 8-9 dan salinitas 25 ppt.

Isnansetyo dan Kurniastuty (1995) yang menyatakan suhu optimal untuk $S$. platensis skala laboratorium adalah $25-35$ ${ }^{\circ} \mathrm{C}$. Untuk suhu optimumnya berkisar antara $35-37{ }^{\circ} \mathrm{C}$, sedangkan suhu minimumnya antara $18-20{ }^{\circ} \mathrm{C}$ dan maksimum $37-40$ ${ }^{\circ} \mathrm{C}$. Suhu air akan mempengaruhi proses pertukaran zat, kadar oksigen dan laju reaksi kimia. Suhu air dipengaruhi oleh intensitas cahaya yang berasal dari lampu dan juga radiasi sinar matahari. Suhu selama penelitian sesuai untuk pertumbuhan $S$. platensis karena berada dalam kisaran yang normal. Untuk derajat keasaman $(\mathrm{pH})$ S. platensis dapat tumbuh hingga mencapai $\mathrm{pH}$ 9. Menurut Sintya (2018) kadar salinitas air untuk pertumbuhan $S$. platensis yang baik adalah adalah $25 \%$.

\section{Biomassa S. platensis Pada Kultur Dengan Pemberian Warna Cahaya Yang Berbeda.}

Pertumbuhan biomassa S. platensis dengan perlakuan warna cahaya kuning memberikan pengaruh hasil yang lebih baik dibandingkan dengan warna cahaya merah dan biru (Gambar 3). Pertumbuhan biomassa mengalami peningkatan dari hari ke-0 sampai hari ke-10, setelah itu jumlah biomassa ini mengalami penurunan sampai pada hari ke-14. 


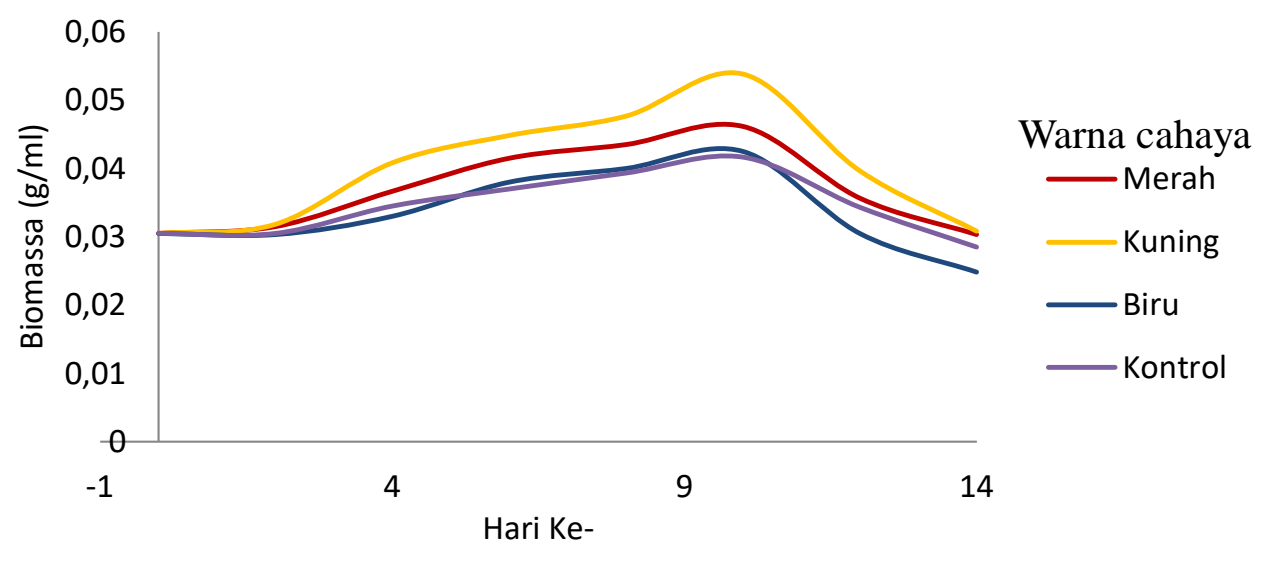

Gambar 1. Pertumbuhan Biomassa S. platensis pada setiap perlakuan

Pada Gambar 1 dapat dilihat biomassa tertinggi didapat pada pemberian warna cahaya kuning dibanding pemberian warna cahaya merah dan biru. Cahaya kuning merupakan cahaya yang bagus untuk dimanfaatkan oleh $S$. platensis dalam melakukan fotosintesis. Dapat diamati dari hari ke-0 sampai hari ke-2 warna cahaya kuning, merah dan biru masih belum mengalami pertumbuhan karena masih beradaptasi, dimana terjadi peyesuaian sel terhadap linglungan baru. Dari hari ke-2 sampai hari ke-4 warna cahaya kuning mengalami pertumbuhan yang sangat cepat berbeda dengan pengaruh warna cahaya merah dan biru yang mulai nampak pertambahan biomassa nya pada hari ke-6 dan sama-sama memuncak pada hari ke-10.

Dilihat dari berat biomassa bahwa warna cahaya yang memberikan hasil terbaik berturut-turut yaitu kuning $>$ merah $>$ biru > kontrol. Pada pemberian cahaya merah dan cahaya biru dapat meningkatkan konsentrasi $\beta$-karoten, cahaya hijau meningkatkan pembentukan fikosianin, sedangkan cahaya merah dan cahaya putih tidak berpengaruh (Santosa, 2007).

Jika dilihat dari kandungan klorofil yang dihasilkan seperti penelitian yang telah dilakukan Wicaksono (2014) yang menyatakan bahwa hasil pemberian spektrum cahaya merah terhadap kandungan klorofil-a dan klorofil-b tiap sel Spirulina $s p$. tidak berbeda nyata $(\mathrm{p}>0,05)$ dengan pemberian spektrum putih. Akan tetapi kandungan klorofil tertinggi didapat pada pemberian spektrum merah dibanding pemberian spektrum biru dan putih. Hal tersebut menunjukan spektrum merah lebih banyak diserap sehingga dapat meningkatkan kandungan klorofil.

Hasil penelitian tentang pertumbuhan biomassa ini dan kandungan klorofil oleh Wicaksono (2014) sesungguhnya tidak jauh berbeda mengingat bahwa warna cahaya kuning memiliki pengaruh yang baik terhadap pertumbuhan biomassa $S$. Platensis karena warna cahaya kuning pada lampu pijar memberikan warna yang mendekati warna cahaya matahari dimana energi foton yang dipakai untuk pertumbuhan akan tersedia, tetapi belum tentu menjadi yang terbaik terhadap kandungan klorofil a dan klorofil $\mathrm{b}$ tiap sel Spirulina. Menurut Campbell (2002) klorofil-a sangat baik menyerap spektrum merah. Spektrum merah dengan panjang gelombang 630-675 $\mathrm{nm}$ ini nanti dimanfaatkan untuk menghasilkan energi dalam proses fotosistem I dan fotosistem II. Spektrum merah dapat diserap maksimal untuk pembentukan klorofil-a dan klorofilb Spirulina sp. karena tiap fitoplankton 
memiliki spektrum absorbsi cahaya yang berbeda (Mercado et al., 2004). Foton atau energi cahaya yang ditangkap oleh molekul klorofil akan menyebabkan perubahan kondisi molekul klorofil dari ground state ke excitation state. Selama perubahan kondisi tersebut molekul klorofil butuh energi yang seimbang dan diambil dari foton yang ditangkap oleh molekul klorofil..

\section{ANOVA}

Hasil_Biomassa

\begin{tabular}{|l|r|r|r|r|r|}
\hline & Sum of Squares & Df & Mean Square & F & Sig. \\
\hline Between & 0,000 & 3 & 0,000 & 10.265 & 0,004 \\
Groups & 0,000 & 8 & 0,000 & & \\
Within Groups & 0,000 & 11 & & & \\
Total & & & & \\
\hline
\end{tabular}

Hasil analisis pertumbuhan biomassa (rata-rata setiap penyamplingan) S. platensis menggunakan Uji ANOVA diperoleh nilai signifikansi 0,004 (Sig.<0,05) yang berarti warna cahaya yang berbeda berpengaruh terhadap biomassa $S$. platensis. Hal ini menunjukkan bahwa $\mathrm{H}_{0}$ ditolak dan $\mathrm{H}_{1}$ diterima artinya terdapat pengaruh antara pemberian warna cahaya dengan pertumbuhan S. platensis. Hasil uji tersebut dapat dilihat pada Lampiran 6.

Dari hasil analisis uji lanjut diperoleh bahwa pemberian warna cahaya kuning lebih baik dibandingkan warna cahaya lainnya dengan nilai signifikan kuning dan merah $(0,041)$, kuning dan biru $(0,001)$, kuning dan kontrol $(0,002)$. Perbandingan warna cahaya kontrol terhadap merah dan biru tidak berbeda nyata dengan masing-masing nilai signifikan 0,088 dan 0,517. Nilai signifikan antara kontrol terhadap pemberian warna cahaya kuning dalam memiliki perbedaan yang sangat nyata $(0,002)$.

\section{KESIMPULAN DAN SARAN}

\section{Kesimpulan}

Dari hasil penelitian ini disimpulkan bahwa warna cahaya berpengaruh nyata terhadap pertumbuhan biomassa $S$. platensis. Warna cahaya kuning memberikan dampak pertumbuhan biomassa yang terbaik, diikuti oleh warna cahaya merah dan cahaya biru.

\section{Saran}

Perlu adanya penelitian lebih lanjut untuk mengetahui pengaruh pemberian warna cahaya terhadap pertumbuhan biomassa $S$. platensis dengan mengukur kandungan nutrien yang ada dalam media kultur karena dalam penelitian ini peneliti hanya mengukur salinitas, $\mathrm{pH}$ dan suhu. 


\section{DAFTAR PUSTAKA}

1. Reinehr, C.O., Costa, J.A.V. (2006). Repeated Batch Cultivation of The Microalga Spirulina platensis. J. Microbiol. \& Biotech Volume 22 Pages 937-943.

2. Campbell, N. A., J. B. Reece and L. G. Mitchell. (2002). Biologi V : 1st Edition. Erlangga. Jakarta.

3. Ekawati, A. W. (2005). Diktat Kuliah Budidaya Pakan Alami. Fakultas Perikanan Universitas Brawijaya.

4. Isnansetyo, A., dan Kurniastuty. (1995). Teknik kultur phytoplankton dan zooplankton.Kanisius:Yogyakarta.

5. Kusriningrum,R. (2008). Perancangan Percobaan. Universitas Airlangga. Surabaya. hal. 43-51.

6. Santosa, V. Leenawaty, L. (2007). Cultivation Of Spirulina. Volume 1(2) Pages 16.

7. Sintya, M. (2018). Pengaruh Perbedaan Salinitas Terhadap Pertumbuhan Biomassa Kultivasi Mikroalga Spirulina platensis Pada Skala Semi Outdoor Di Fakultas Perikanan dan Kelautan Universitas Riau. Skripsi. Program Studi Sarjana, Universitas Riau.

8. Wicaksono, G. (2014). Pengaruh Pemberian Spektrum Cahaya Berbeda Terhadap Kandungan Klorofil Spirulina sp. Surabaya (ID): Universitas Airlangga. 